Jpn. J. Limnol., 48, 4, 257-264, 1987.

\title{
Studies on Denitrification in the Water Column of Lake Kizaki and Lake Fukami-Ike
}

\author{
Hisayoshi TERAI
}

\begin{abstract}
Denitrifying activities in two freshwater lakes, Lake Kizaki during October to December 1986 and Lake Fukami-ike during July to August 1985 and in July 1986, were estimated by the acetylene biockage method. Relationships between the denitrifying activities and the concentration of denitrifying intermediates such as $\mathrm{NO}_{2}{ }^{-}$and $\mathrm{N}_{2} \mathrm{O}$ in the water column of the two lakes were analyzed. Denitrifying activity in L. Fukami-ike was essentially dependent on $\mathrm{NO}_{2}{ }^{-}$ concentration, in two ways. A positive correlation was found between denitrifying activity and in situ $\mathrm{NO}_{2}{ }^{-}$concentration, while in some cases remarkable denitrifying activities were found in the $\mathrm{NO}_{2}{ }^{-}$-depleted layer and correlated with the maximally accumulated $\mathrm{NO}_{2}{ }^{-}$concentration. On the other hand, a better correlation of denitrifying activity with $\mathrm{N}_{2} \mathrm{O}$ concentration was found in L. Kizaki.

Mineralization of ${ }^{14} \mathrm{C}$-acetate and its coupling with the denitrification were also compared in the two lakes. Mineralized ${ }^{14} \mathrm{CO}_{2}$ plotted against the total uptaken ${ }^{14} \mathrm{C}$-acetate fell in a regression line with the same slope of 0.34 not only even in $\mathrm{NO}_{3}{ }^{-}$-enhanced uptake of the substrate, but also in both L. Fukami-ike (at 4-4.5 m depth on 20 July 1986) and L. Kizaki (at 21-24 m depth on 2 December 1986).
\end{abstract}

Key words : Denitrification, acetylene blockage, $\mathrm{N}_{2} \mathrm{O}$, mineralization ratio.

\section{Introduction}

Development of the denitrifying activity process in the water column of the two freshwater lakes, L. Kizaki and L. Fukami-ike (located in northern and southern part of Nagano Prefecture in central Japan, respectively), has been recently reported by TERAI $e t$ al. (1987a, b). In Lake Fukami-ike, from just after the vernal overturn to the summer stagnation, while in Lake Kizaki from late summer stagnation to just before winter circulation, denitrifying activities developed in the hypolimnion. These developments of the denitrification process were essentially the same in both lakes, because the denitrifying activities developed concomitant with the development of the anoxic conditions. To determine other differences and similarities of the denitrification process in the two lakes, further studies were carried out during the period when higher activities were expected. In this study, the characteristics of denitrifying activity of both lakes are described, especially in relation to the in situ concentration of $\mathrm{NO}_{2}{ }^{-}$or $\mathrm{N}_{2} \mathrm{O}$ and the mineralization ratio to total uptake of ${ }^{14} \mathrm{C}$-acetate.

\section{Materials and methods}

Observation and lake water sampling were carried out on 14-15 and 28-29 July, 29-30 August 1985, and 20-21 July 1986 in Lake Fukami-ike, and also on 67 October, 4-6 November, and 29 November-2 December in Lake Kizaki. Sampling stations were set up near the point of maximum depth of $8.5 \mathrm{~m}$ in L. Fukami-ike and $28.5 \mathrm{~m}$ in L. Kizaki, respectively.

Water temperature was measured by a thermistor thermometer (Toho Dentan ET-5), and dissolved oxygen estimated either by an oxygen electrode (YSI Model 57) or the Winkler's titration method (in observations in 1986). Water samples were collected with a usual Van Dorn sampler $(2.0 l$ capacity) in L. Kizaki, but in L. Fukami-ike with a polycarbonate sampler, having a $2.0 l$ capacity and $31 \mathrm{~cm}$ net height (Rigosha SR-sampler).

Lake water samples for assay of inorganic nitrogen concentration were filtrated by Whatmann GF/ $\mathrm{C}$ filters and frozen at lakeside immediately after the sampling.

Inorganic nitrogen concentrations were estimated by a Technicon Autoanalyzer except for the data of 
August 1985 in L. Fukami-ike, which was obtained by usual manual determinations (A. Yagi, personal communication. cf. YAGI et al., 1983). Ammonium ion was analyzed according to Technicon Industrial Method (1973) or U. S. EPA (1974) with a slight modification. Nitrate and nitrite ions were obtained according to the Technicon Industrial Method (1972). Denitrifying activity was estimated by the acetylene blockage method described earlier (TERAI et al., 1987a).

Mineralization and total uptake of ${ }^{14} \mathrm{C}$-acetate were estimated as follows: Glass vials ( $c a .120 \mathrm{ml}$ capacity) were filled and overflowed with sample water and capped with rubber stopper. Aliquots of $\mathrm{U}-{ }^{14} \mathrm{C}$-acetate (Amersham, $50 \mu \mathrm{Ci} / 0.86 \mu$ mole) diluted with cold acetate carrier were injected into the sample vials in duplicate at 2 or 3 concentrations for each sampling water with or without $\mathrm{NO}_{3}{ }^{-}$. Final concentrations and radioactivities of added acetate were $6.6-11.4 \mu \mathrm{gC} \cdot 1^{-1}\left(3.25 \mu \mathrm{Ci} \cdot 1^{-1}\right)$ in L. Kizaki and $148-492 \mu \mathrm{gC} \cdot 1^{-1}\left(1.23-4.1 \mu \mathrm{Ci} \cdot 1^{-1}\right)$ in L. Fukami-ike, respectively. After injection of ${ }^{14} \mathrm{C}-$ acetate, each vial was clipped with an aluminum cap and incubated at in situ depth (in L. Fukami-ike) for $4 \mathrm{hr}$ or in an incubator controlled at in situ temperature $\pm 2^{\circ} \mathrm{C}$ for $2 \mathrm{hr}$ under dark condition (in L. Kizaki). Incubation was terminated by injecting $3 \mathrm{ml}$ of formalin $(37 \%)$ with a syringe through the rubber cap by overflowing the sample water into another syringe.

For the determination of total uptake and mineralization of ${ }^{14} \mathrm{C}$-acetate, $20 \mathrm{ml}$ of the incubated sample water was withdrawn from each vial through the rubber cap and filtered with a membrane filter (Millipore GS, $24 \phi$ ). Then $1 \mathrm{ml}$ of $2 \mathrm{~N} \mathrm{H}_{2} \mathrm{SO}_{4}$ was added to each vial, $\mathrm{CO}_{2}$-free air through a sodaasbestos trap was bubbled into the vial and finally ${ }^{14} \mathrm{CO}_{2}$ degassed was trapped in $1.5 \mathrm{ml}$ of monoethanolamine-methyl cellosolve mixture ( 1 : 2) in a small tube (i.d. $8.5 \mathrm{~mm}$ ). Eight sets of sampling vial- ${ }^{14} \mathrm{CO}_{2}$-absorbing system were connected with a manifold and sucked with an air pump for $2 \mathrm{hr}$.

Radioactivity of the filter and $0.5 \mathrm{ml}$ of ${ }^{14} \mathrm{CO}_{2}$ absorbent were counted with a $5 \mathrm{ml}$ scintillation cocktail (Dojin Scintisol XE-H) and a liquid scintillation counter (Aloka LSC-651).

\section{Results and discussion}

In 1985, denitrifying activity was well developed in L. Fukami-ike during April to July (TERAI et al., 1987b). Further studies on the denitrifying activity in the lake were continued during the summer stagnation period in 1985. Figure 1 shows the results of denitrifying activity measurements and vertical profiles of environmental factors. It is evident from the profile of $\mathrm{NO}_{3}{ }^{-}$concentration that $\mathrm{NO}_{3}{ }^{-}$was rapidly consumed during this period between $3-5 \mathrm{~m}$ depth. It is noticeable that $\mathrm{NO}_{2}{ }^{-}$ maxima, which reached $10 \mu \mathrm{g}$-at $\mathrm{N} \cdot 1^{-1}$ in July, were retained at $3.5 \mathrm{~m}$ depth during this period. Although in situ $\mathrm{N}_{2} \mathrm{O}$ concentrations were lower than $\mathrm{NO}_{2}{ }^{-}$concentrations, there were small maxima at 4 $\mathrm{m}$ depth in July, so that sequential peaks of $\mathrm{NO}_{3}{ }^{-}$, $\mathrm{NO}_{2}{ }^{-}$and $\mathrm{N}_{2} \mathrm{O}$ were found in July (Fig. $1 \mathrm{a}, \mathrm{b}$ ).

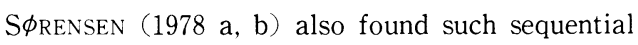
peaks of nitrogen compounds in coastal marine sediments and detected denitrifying activities. Thus vertical profiles of $\mathrm{NO}_{3}{ }^{-}, \mathrm{NO}_{2}{ }^{-}$, and $\mathrm{N}_{2} \mathrm{O}$ in July suggested the denitrifying activity, which was confirmed by the acetylene blockage method. Significant amounts of denitrifying activities were detected on $15\left(0.3-0.4 \mu \mathrm{g}-\right.$ at $\mathrm{N} \cdot 1^{-1} \cdot \mathrm{day}^{-1}$ between $3.0-3.75 \mathrm{~m}$ depth $)$ and on $29\left(0.5^{-1} .2 \mu \mathrm{g}\right.$-at $\mathrm{N} \cdot 1^{-1}$. day $^{-1}$ between $3.25-4.0 \mathrm{~m}$ depth) July (Fig. 1 a. b). Maximum denitrifying activity of $1.2 \mu \mathrm{g}$-at $\mathrm{N} \cdot 1^{-1}$. $\mathrm{day}^{-1}$ exceeded the maximum one recorded on $2 \mathrm{July}$ 1985 (TERAi et al., 1987b).

On 29 August, however, denitrifying activities fell below $0.05 \mu \mathrm{g}$-at $\mathrm{N} \cdot 1^{-1} \cdot \mathrm{day}^{-1}$. Enhancement of the activity by the addition of $\mathrm{NO}_{3}{ }^{-}(10 \mu \mathrm{g}$-at $\mathrm{N}$. bottle ${ }^{-1}, c a .80 \mu \mathrm{g}-$ at $\left.\mathrm{N} \cdot 1^{-1}\right)$ indicates that the low in situ $\mathrm{NO}_{3}^{-}$or $\mathrm{NO}_{2}^{-}$concentration limited the in situ denitrifying activity at this time (Fig.1 c).

Another profile of denitrifying activity in this lake was observed on 20 July 1986 (Fig. 1 d). Although it is strange that significant denitrifying activity was found rather in $\mathrm{NO}_{3}{ }^{-}$- and $\mathrm{NO}_{2}{ }^{-}$- depleted layer $\left(\mathrm{NO}_{3}{ }^{-}+\mathrm{NO}_{2}{ }^{-}\right.$concentration was $1.3 \mu \mathrm{g}-$ at $\left.\mathrm{N} \cdot 1^{-1}\right)$, the similar profiles were sometimes found(on 25 May and 2 July 1985: TerAi et al., 1987b: on 30 April 1986: Terai, submitted to Jpn. J. Limnol.).

As the denitrification in Lake Kizaki was expected to be active in late autumn according to our recent study (TERA et al., 1987a), further observation and experiments were performed from October to December in 1986. Figure 2 shows the results of denitrifying activity measurements as well as vertical profiles of water temperature and dissolved oxygen, $\mathrm{NO}_{3}{ }^{-}, \mathrm{NO}_{2}{ }^{-}$and $\mathrm{N}_{2} \mathrm{O}$ concentrations in the hypolimnion. Nitrate consumption was clear below 22, 21 and $20 \mathrm{~m}$ depth with $\mathrm{NO}_{2}{ }^{-}$maximum at 24,23 

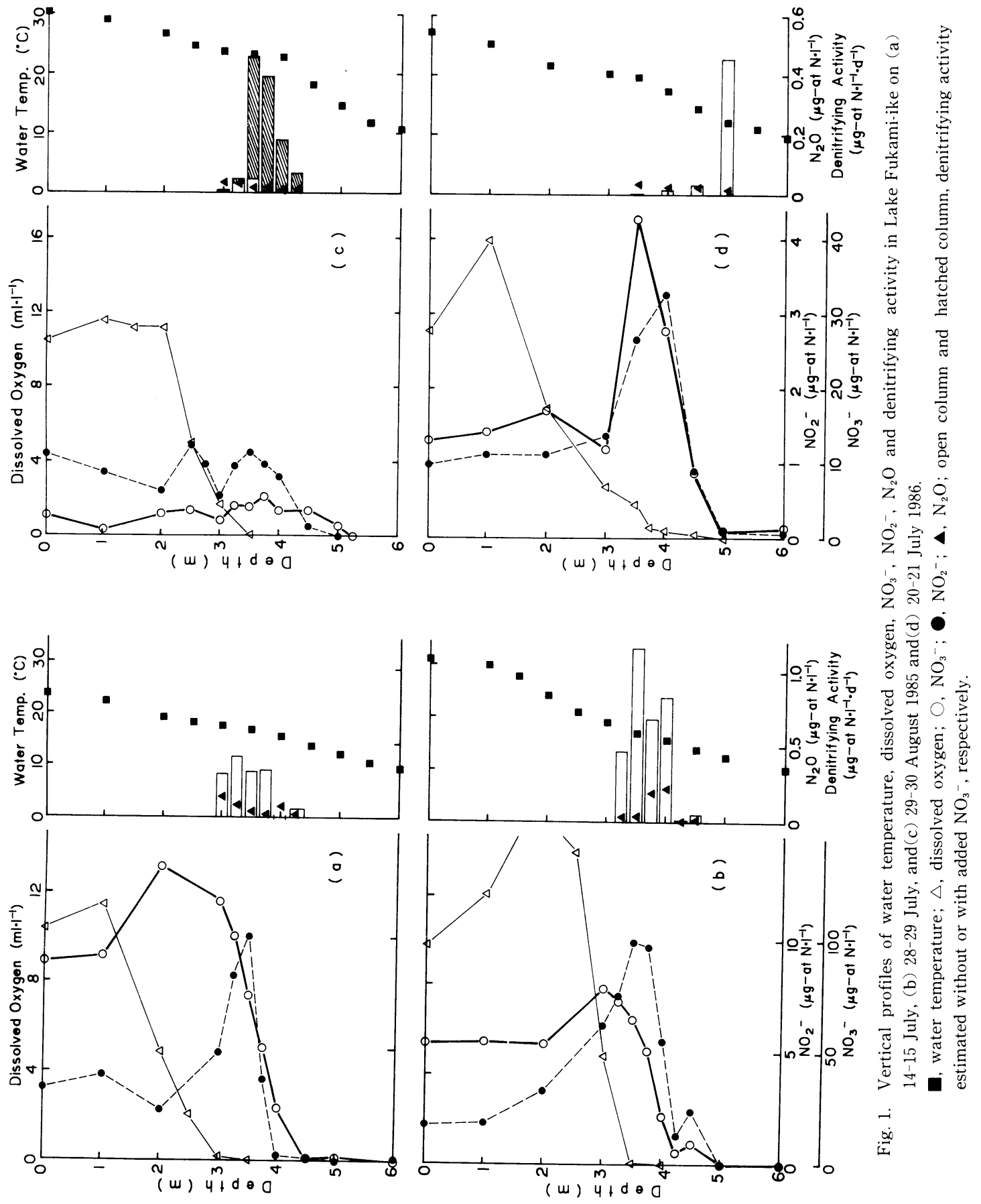


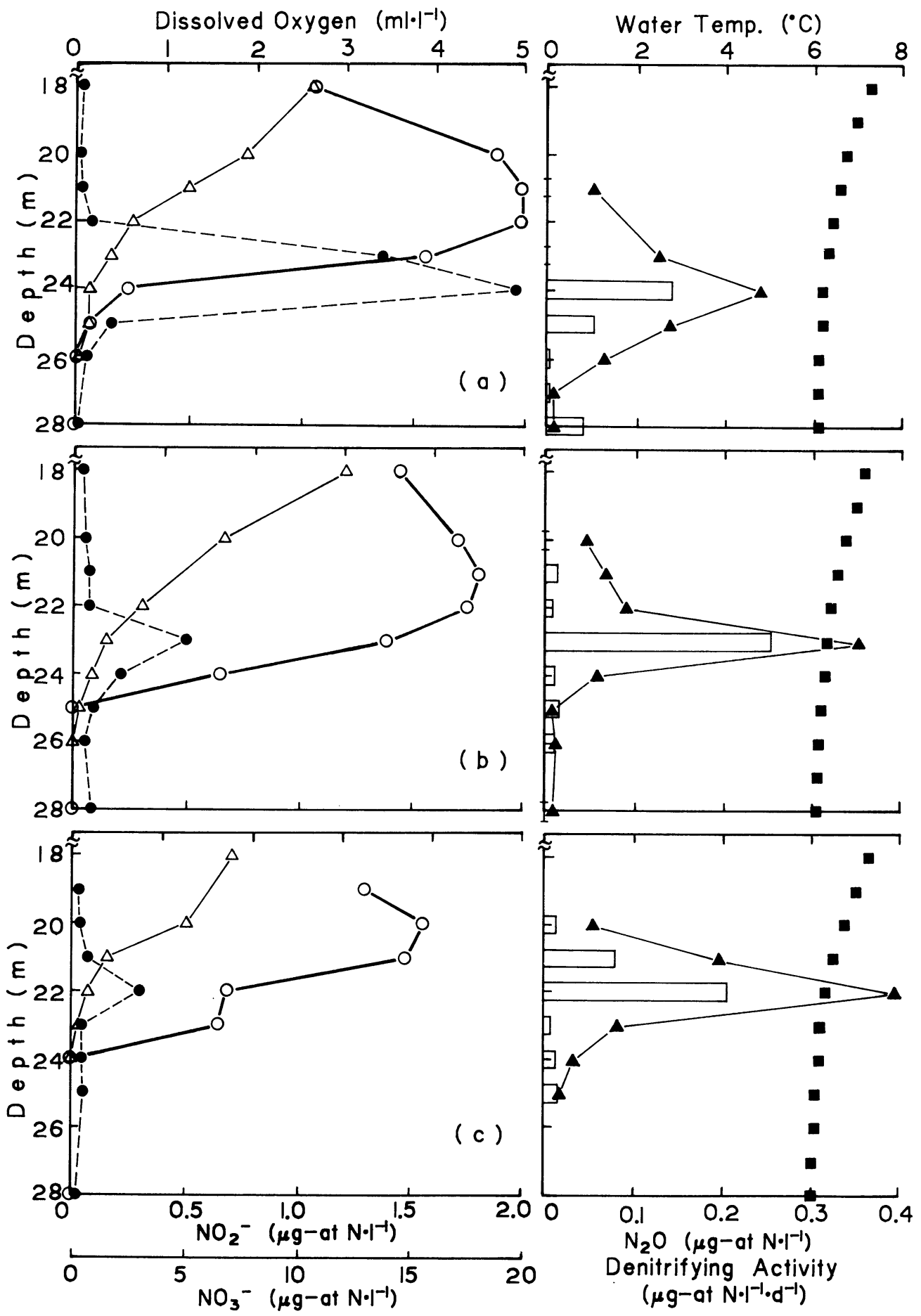

Fig. 2. Vertical profiles of water temperature, dissolved oxygen, $\mathrm{NO}_{3}{ }^{-}, \mathrm{NO}_{2}{ }^{-}, \mathrm{N}_{2} \mathrm{O}$ and denitrifying activity in the hypolimnion of Lake Kizaki on (a) 6-7 October, (b) 4-6 November and (c) 29 November-2 December 1986.

$\mathbf{\square}$, water temperature: $\triangle$, dissolved oxygen; $\bigcirc, \mathrm{NO}_{3}^{-} ; \boldsymbol{\bullet}, \mathrm{NO}_{2}^{-} ; \mathbf{\Delta}, \mathrm{N}_{2} \mathrm{O}$; and open column, denitrifying activity. 
and $22 \mathrm{~m}$ depth on 6 October, 5 and 30 November, respectively. In situ $\mathrm{N}_{2} \mathrm{O}$ concentration and denitrifying activities reached maximum at the same depths as $\mathrm{NO}_{2}{ }^{-}$maxima were found. Maximum amounts of accumulated $\mathrm{NO}_{2}{ }^{-}\left(2-0.3 \mu \mathrm{g}\right.$ at $\left.\mathrm{N} \cdot 1^{-1}\right)$ and $\mathrm{N}_{2} \mathrm{O}\left(0.2-0.4 \mu \mathrm{g}\right.$ at $\left.\mathrm{N} \cdot 1^{-1}\right)$ observed in this study were rather lower than those of our previous study (Terai et al., 1987; YOH et al., 1983). Maximum denitrifying activities observed in the present study $\left(0.14,0.25\right.$ and $0.21 \mu \mathrm{g}$ at $\mathrm{N} \cdot 1^{-1} \cdot \mathrm{d}^{-1}$ on 6 October, 5 and 30 November, respectively) were also lower than those of our previous study (TERAI et al., 1987a).

For further understanding of the characteristics of denitrification in the two lakes, the relationship between denitrifying activity and in situ concentration of nitrogen compound was analyzed. In Lake Fukami-ike, two types of denitrification were observed. In July 1985, denitrifying activities and in situ $\mathrm{NO}_{2}{ }^{-}$concentrations were roughly correlated with a correlation coefficient of 0.75 ( $p<0.01$, Fig. $3 a)$. The correlation was not changed much by the addition of August, which were omitted for the plotting because of the very low activities. In the other type of denitrification observed on 21 July 1986, a strong correlation was found between the maximum concentration of $\mathrm{NO}_{2}^{-}$and the denitrifying activity in the layer where $\mathrm{NO}_{3}{ }^{-}$and $\mathrm{NO}_{2}{ }^{-}$had just been depleted (Fig. 3b). In the first type of denitrification, $\mathrm{NO}_{2}{ }^{-}$seems to accumulate as a result of denitrifying activity which reduces the $\mathrm{NO}_{3}{ }^{-}$mainly supplied by inflowings, so the denitrifying activity had a direct correlation with in situ $\mathrm{NO}_{2}{ }^{-}$concentration.

The relationship between the denitrifying activity derived from ETS activity measurement and the in situ $\mathrm{NO}_{2}{ }^{-}$concentration was shown in the secondary $\mathrm{NO}_{2}{ }^{-}$maximum layer of the eastern tropical South Pacific Ocean (CODISPOTI and PACKARD, 1980). According to their data, $10 \mu \mathrm{g}$-at $\mathrm{N} \cdot 1^{-1} \mathrm{NO}_{2}{ }^{-}$concentration corresponded to denitrifying activity of $0.05 \mu \mathrm{g}$-at $\mathrm{N} \cdot 1^{-1} \cdot \mathrm{d}^{-1}$, which was one order or more lower than that estimated in L. Fukami-ike.

On the other hand, in the second type of denitrification, denitrifying activities did not coincide with in situ $\mathrm{NO}_{2}{ }^{-}$concentration but seemed to depend on the accumulated $\mathrm{NO}_{2}{ }^{-}$, which would be produced through the activity of nitrification and/or nitrate reduction to nitrite. There are no available data on nitrification and nitrate reduction in Lake Fukami-ike, so simultaneous measurement of denitrification, nitrification and nitrate reduction is
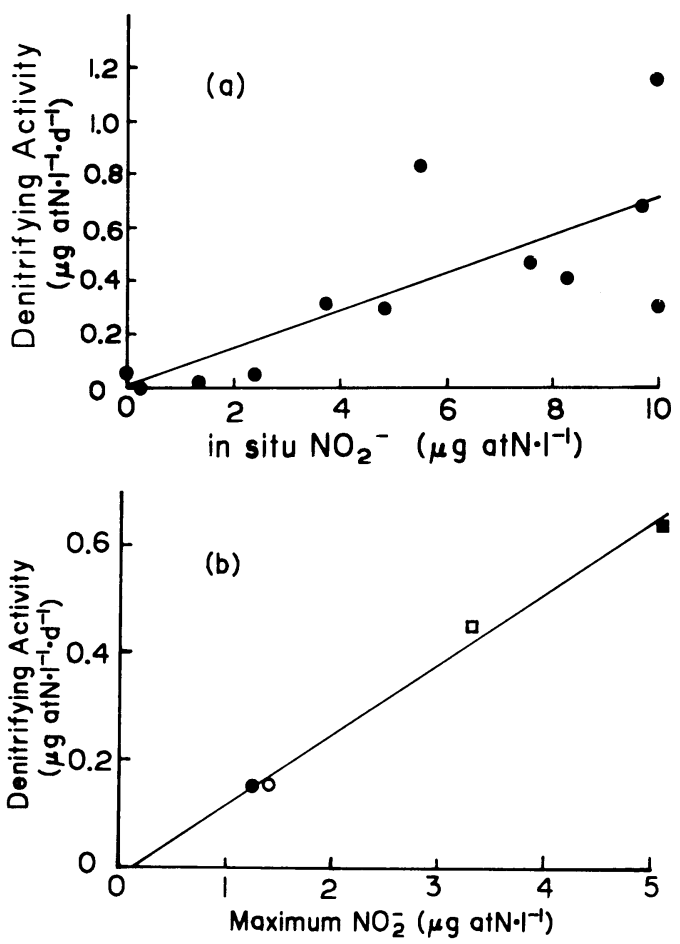

Fig. 3. Relationship between $\mathrm{NO}_{2}{ }^{-}$concentration and denitrifying activity in Lake Fukami-ike.

(a) Denitrifying activities were plotted against in situ $\mathrm{NO}_{2}{ }^{-}$concentrations. Data were derived from Fig. 1. $a$ and b. (b) Denitrifying activities in $\mathrm{NO}_{3}{ }^{-}$just depleted layer were plotted against maximum $\mathrm{NO}_{2}{ }^{-}$concentration. Data were obtained on 21 July ( $\square$ ) and 30 April (O) 1986 and on $2 \operatorname{July}(\mathbf{\square})$ and $\left.25 \operatorname{May}()^{\prime}\right) 1985$.

needed to confirm the above hypothesis.

In Lake Kizaki, the denitrifying activities showed a correlation rather with in situ $\mathrm{N}_{2} \mathrm{O}$ concentrations with a higher coefficient of correlation ( $r=0.94$, $P<0.001$ Fig. 4$)$, in contrast with a lower correlation of those in L. Fukami-ike $(r=0.57, P<0.05)$ and a correlation between denitrifying activity and in situ $\mathrm{NO}_{2}{ }^{-}$concentration in L. Kizaki ( $r=0.51$, $P<0.05$ ).

Although lower levels of $\mathrm{N}_{2} \mathrm{O}$ and $\mathrm{NO}_{2}{ }^{-}$and lower denitrifying activity were observed in this study compared with our previous one (TERAI et al., $1987 \mathrm{a}$ ), the $\mathrm{N}_{2} \mathrm{O}$ concentration was comparable with or exceeded the $\mathrm{NO}_{2}{ }^{-}$concentration in early (Fig. 2b) or late (Fig. 2c) November, as described in $\mathrm{YOH}$ et al. (1983, 1987). Extrapolation of $\mathrm{N}_{2} \mathrm{O}$ concentration in Fig. 4 to the maximum $\mathrm{N}_{2} \mathrm{O}$ concentration $\left(2.6 \mu \mathrm{g}\right.$-at $\left.\mathrm{N} \cdot 1^{-1}\right)$ observed on 2 December 1984 


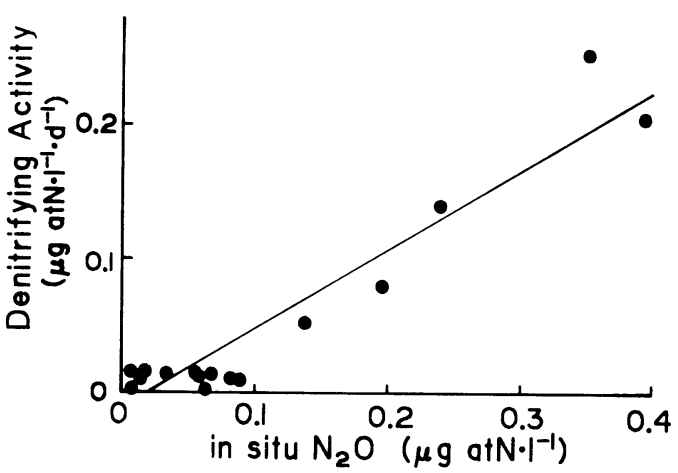

Fig. 4. Relationship between in situ $\mathrm{N}_{2} \mathrm{O}$ concentration and denitrifying activity in Lake Kizaki.

Data were derived from Fig. 2 a, b and c.

gives a denitrifying activity of $1.53 \mu \mathrm{g}$-at $\mathrm{N} \cdot \mathrm{l}^{-1} \cdot \mathrm{d}^{-1}$, which is not far from the observed maximum denitrifying activity of $1.96 \mu \mathrm{g}$-at $\mathrm{N} \cdot \mathrm{l}^{-1} \cdot \mathrm{d}^{-1}$ in the same water depth (Terai et al., 1987a).

Differences in denitrifying activity which were differently correlated with in situ nitrogen com. pounds in either L. Fukami-ike or L. Kizaki might reflect a difference of available organic matter level in the two lakes. ANDERSON et al. (1982) speculated in a model of oceanic denitrification that a higher organic level would accumulate $\mathrm{NO}_{2}{ }^{-}$, whereas a lower one would not. HAHN (1981) also indicated the possibility that a higher organic matter level would stimulate $\mathrm{NO}_{3}{ }^{-}$reduction more than $\mathrm{NO}_{2}{ }^{-}$ reduction and that a lower level was preferable for denitrification to $\mathrm{N}_{2} \mathrm{O}$ and $\mathrm{N}_{2}$. If this hypothesis is applicable, the difference in dissolved organic carbon level between L. Fukami-ike (usually $4-8 \mathrm{mgC}$. $1^{-1}$, YAGI, 1986) and L. Kizaki (usually 0.5-1.0 mgC. $1^{-1}$, Kato and SAкамото, 1981) would differentiate the accumulation of $\mathrm{NO}_{2}{ }^{-}$or $\mathrm{N}_{2} \mathrm{O}$ in the denitrification of the two lakes. Further experimental studies are needed to confirm this hypothesis.

Another approach was undertaken to compare the denitrification in the two lakes. The mineralization ratio to the total uptake of a radioactive substrate was estimated on 20 July 1986 in L. Fukami-ike and on 2 December 1986 in L. Kizaki (Fig. 5). According to HOBBIE and CRAWFORD (1969), the mineralization ratio would reflect the metabolic pathway of the used substrate in the community under study.

In L. Fukami-ike, despite the lower denitrifying activity at the examined depths (cf. Fig. 1d), it was shown that uptake activity was remarkably higher at $4.5 \mathrm{~m}$ depth than at $4 \mathrm{~m}$ depth, and that signifi-
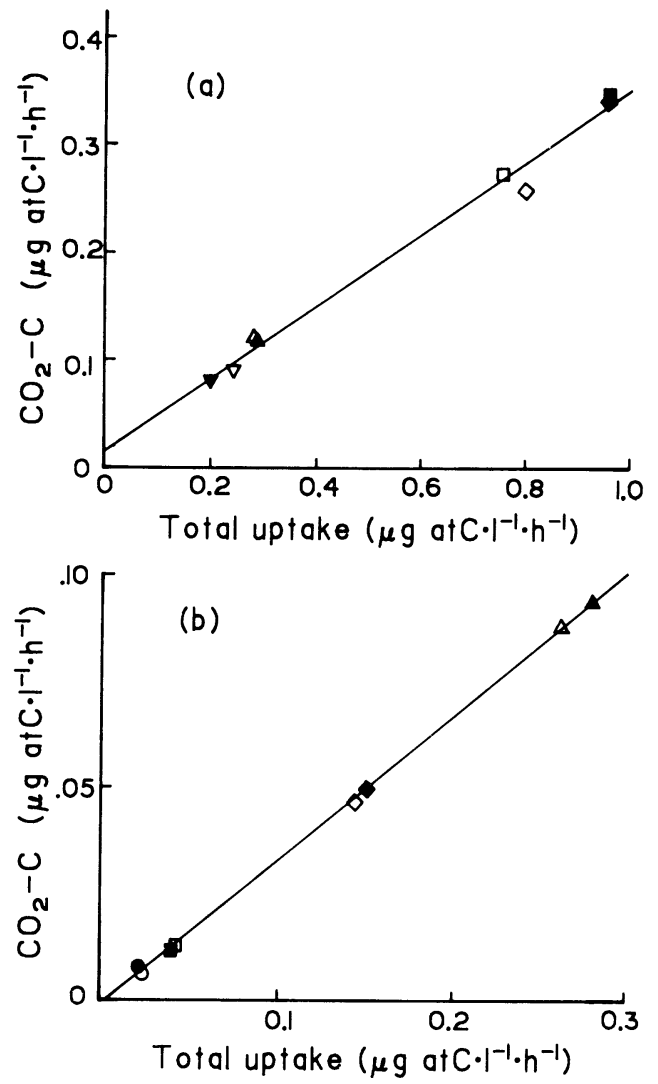

Fig. 5. Comparison of mineralization efficiency of $\mathrm{U} \cdot{ }^{14} \mathrm{C}$-Acetate by the denitrifying community in (a) Lake Fukami-ike on 20 July 1986 and (b) Lake Kizaki on 2 December 1986.

Symbols are as followings: (a) $\square$ and $\diamond, 4.5 \mathrm{~m}$ depth incubated with 0.15 and $0.49 \mathrm{mgC} \cdot 1^{-1}$ substrate, respectively; $\nabla$ and $\triangle, 4.0 \mathrm{~m}$ depth incubated with 0.15 and $0.49 \mathrm{mgC} \cdot 1^{-1}$, respectively. (b) $\diamond, \triangle, \square$, and $\bigcirc, 21,22,23,24 \mathrm{~m}$ depth, respectively. Substrate concentration was $5.8 \mu \mathrm{g}$ $\mathrm{C} \cdot 1^{-1}$ except for at $22 \mathrm{~m}$ depth where data with $11.4 \mu \mathrm{g} \mathrm{C} \cdot 1^{-1}$ substrate were used because almost all of the substrate were consumed up at lower concentration.

Closed symbols indicate incubation with added $\mathrm{NO}_{3}^{-}\left(10 \mu \mathrm{g}\right.$ at $\mathrm{N} \cdot$ bottle $\left.{ }^{-1}\right)$ both in (a) and (b).

cant enhancement by $\mathrm{NO}_{3}{ }^{-}$addition $(81.3 \mu \mathrm{g}$-at $\mathrm{N}$ $1^{-1}$ ) was only observed at $4.5 \mathrm{~m}$ depth, where in situ $\mathrm{NO}_{3}{ }^{-}\left(8 \mu \mathrm{g}\right.$-at $\left.\mathrm{N} \cdot \mathrm{l}^{-1}\right)$ was rather low. This result indicated also that all plots, for which mineralized carbon were plotted against total uptaken carbon, linearly regressed with a slope of $0.339(r=0.994)$. This slope reveals the mineralization ratio of this community in L. Fukami-ike. It is noticeable that 
the mineralization ratio in the $\mathrm{NO}_{3}{ }^{-}$enhanced mineralization, which was essentially responsible for denitrfication itself, was the same as that of nonenhanced community or a less active one ( $4 \mathrm{~m}$ depth). Therefore, it is concluded that the denitrifying community in L. Fukami-ike had a mineralization ratio of $34 \%$ with $\mathrm{U}^{-14} \mathrm{C}$-acetate.

In $\mathrm{L}$. Kizaki, ${ }^{14} \mathrm{C}$-uptake activities coincided well with the denitrifying activities which were maximum at $22 \mathrm{~m}$ depth, followed by $21 \mathrm{~m}$ depth (cf. Fig. 2c). Small but distinct enhancements of ${ }^{14} \mathrm{C}$-uptake by $\mathrm{NO}_{3}{ }^{-}$addition $\left(81.3 \mu \mathrm{g}-\right.$ at $\left.\mathrm{N} \cdot 1^{-1}\right)$ were evident at $22 \mathrm{~m}$ depth, where there was $7 \mu \mathrm{g}-$ at $\mathrm{N} \cdot \mathrm{l}^{-1} \mathrm{NO}_{3}{ }^{-}$. Also, in L. Kizaki, all plots were linearly regressed with a slope of $0.339(r=0.999)$, the same as in L. Fukami-ike. The mineralization ratio in the $\mathrm{NO}_{3}{ }^{-}$ enhancement was also the same as those of nonenhanced ones. The mineralization ratio of the denitrifying community in L. Kizaki was the same (34\%) as that in L. Fukami-ike.

\section{Acknowledgements}

We are grateful to the Anan Town authorities in Shimoina-gun, Nagano Prefecture for providing the facilities for this research. This study was supported in part by a Grant-in-Aid for Scientific Research (No.61540473) from the Ministry of Education, Science and Culture.

\section{摘 要}

\section{木崎湖おょび深見池湖水中の脱窒について}

長野県の木崎湖（1986年10-12 月）および深見池 (1985 年 7-8 月および 1986 年 7 月) においてアセチレ ン阻害法により湖水中の脱窒活性を測定し, 両湖にお ける脱窒特性を特に, 脱窒中間生成物 $\left(\mathrm{NO}_{2}{ }^{-}, \mathrm{N}_{2} \mathrm{O}\right)$ の蓄積状況および ${ }^{14} \mathrm{C}$ 標識酢酸塩の無機化効率との関 連について比較検討した。

その結果, 深見池における脱窒には $\mathrm{NO}_{2}{ }^{-}$濃度に依 存する二つのタイプが見られた。一つは脱窒活性が現 場 $\mathrm{NO}_{2}{ }^{-}$濃度と直接相関を持つ場合 $(r=0.75)$, も5 一つは $\mathrm{NO}_{2}$ - 極大濃度がその枯渴層における脱窒活性 と相関を持つ場合 $(r=0.99)$ で, 前者は脱窒による $\mathrm{NO}_{2}{ }^{-}$蓄積, 後者は硝化, 硝酸還元, またはその両者 によって蓄積したと考えられる $\mathrm{NO}_{2}^{-}$による脱窒を示 唆するものと考えられた。一方木崎湖における脱窒に おいては, 脱窒極大層は $\mathrm{NO}_{2}{ }^{-} お$ よび $\mathrm{N}_{2} \mathrm{O}$ 蓄積極大層 と一致し, 脱窒活性は現場 $\mathrm{N}_{2} \mathrm{O}$ 濃度と最も良い相関を 示した $(r=0.94)$ 。

${ }^{14} \mathrm{C}$ 標識酢酸塩の総取込量に対する無機化量を取る 之, 深見池（1986 年 7 月 4-4.5 m 層) 木崎湖（1986 年
12 月 21-24 m 層) 共に同一の傾き (0.34) の直線回帰 を示した。また $\mathrm{NO}_{3}{ }^{-}$添加により総取込, 無機化が促 進される場合も同一直線上に回帰することから, 両湖 における脱窒による ${ }^{14} \mathrm{C}$ 標識酢酸塩の無機化効率はそ の直線の傾きから $34 \%$ \%まったく同一と考えられる。

\section{References}

Anderson, J. J., A. Okubo, A. S. Robbins and F. A. RICHARDS (1982): A model for nitrite and nitrate distribution in oceanic oxygen minimum zones. Deep-Sea Res., 29: 1113-1140.

Codispoti, L. A. and T. T. Packard (1980): Denitrification rates in the eastern tropical South Pacific. J. Mar. Res., 38: 453-477.

HaHN, J. (1981): Nitrous oxide in the ocean. In: C. C. Delwiche (ed.), Nitrification, Denitrification and Atmospheric Nitrous Oxide. p.191-240.

Hobbie, J. E. and C. C. CRAwFord (1969): Respiration corrections for bacterial uptake of dissolved organic compounds in natural waters. Limnol. Oceanogr., $14:$ 528-532.

Kato, K. and M. Sakamoto (1981): Diurnal change of ${ }^{14} \mathrm{C}$-glucose uptake by epilimenetic microbes in Lake Kizaki. Jpn. J. Limnol., 42: 250-253.

S $\phi$ RENSEN, J. (1978a): Denitrification rates in a marine sediment as measured by the acetylene inhibition technique. Appl. Environ. Microbiol., $36: 139-143$.

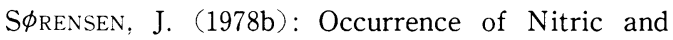
Nitrous Oxides in a coastal marine sediment. Appl. Environ. Microbiol., 36: 809-813.

Technicon Industrial Method (1973): Ammonia in water and seawater. Method No.154-71W/B

Technicon Industrial Method (1972): Nitrate and Nitrite in water and seawater. Method No.158$71 \mathrm{~W} / \mathrm{A}$.

TERAI, H. (1988): Influence of precipitation on development of the denitrification process in Lake Fukami-ike (in press).

Terai, H., M. Yoh and Y. Saijo (1987 a): Active denitrification in the hypolimnetic water column in Lake Kizaki. Jpn. J. Limnol., 48 : 219-224.

Terai, H., M. Yoh and Y. Saijo (1987 b): Denitrifying activity and the population growth of denitrifying bacteria in Lake Fukami-ike. Jpn. J. Limnol., 48 : 211-218.

U. S. Environmental Protection Agency (1974): In "Method for chemical analysis of water and wastes." p.168-174.

YAGI, A. (1986): Dissolved organic carbon and Manganese in the boundary of oxic and anoxic 
layers in Lakes Fukami-ike and Suigetsu-ko. Jpn. J. Limnol., 47 : 291-298.

Yagi, A., I. Shimodaira, H. Terai and Y. Saijo (1983): Seasonal change of chlorophyll- $a$ and bacteriochlorophyll in Lake Fukami-ike. Jpn. J. Limnol., 44: 283-292.

Yoh, M., H. Terai and Y. Saljo (1983): Accumulation of nitrous oxide in the oxygen deficient layer of freshwater lakes. Nature. 301: 327-329.

Yoh, M., H. Terai and Y. SAIJo (1987): Nitrous oxide in freshwater lakes. Arch. Hydrobiol (in press).

(著者: 寺井久慈, 名古屋大学水圏科学研究所, $\bar{\top}$ 464 名古屋市千種区不老町 ; Hisayoshi TERAI, Water Research Institute, Nagoya University, Nagoya 464)

Received: 24 July 1987

Accepted : 29 August 1987 